University of Nebraska - Lincoln

DigitalCommons@University of Nebraska - Lincoln

\title{
Interfacial reactivity of radionuclides: emerging paradigms from molecular-level observations
}

\author{
A.R. Felmy \\ Pacific Northwest National Laboratory, ar.felmy@pnl.gov \\ E.S. Ilton \\ Pacific Northwest National Laboratory \\ K.M. Rosso \\ Pacific Northwest National Laboratory \\ John M. Zachara \\ Pacific Northwest National Laboratory, john.zachara@pnl.gov
}

Follow this and additional works at: https://digitalcommons.unl.edu/usdoepub

Part of the Bioresource and Agricultural Engineering Commons

Felmy, A.R.; Ilton, E.S.; Rosso, K.M.; and Zachara, John M., "Interfacial reactivity of radionuclides: emerging paradigms from molecular-level observations" (2011). US Department of Energy Publications. 277.

https://digitalcommons.unl.edu/usdoepub/277

This Article is brought to you for free and open access by the U.S. Department of Energy at DigitalCommons@University of Nebraska - Lincoln. It has been accepted for inclusion in US Department of Energy Publications by an authorized administrator of DigitalCommons@University of Nebraska - Lincoln. 


\title{
Interfacial reactivity of radionuclides: emerging paradigms from molecular-level observations
}

\author{
A. R. Felmy*, E. S. Ilton, K. M. Rosso and J. M. Zachara \\ Pacific Northwest National Laboratory, Richland, Washington 99352, USA
}

[Received 27 January 2011; Accepted 7 June 2011]

\section{ABSTRACT}

Over the past few decades an increasing array of molecular-level analytical probes has provided new detailed insight into mineral and radionuclide interfacial reactivity in subsurface environments. This capability has not only helped change the way mineral surface reactivity is studied but also how fieldscale contaminant migration problems are addressed and ultimately resolved. Here we review relatively new interfacial reactivity paradigms and assess their implications for future research directions. Specific examples include understanding the following: the role of site-to-site electron conduction at mineral surfaces and through bulk mineral phases and the effects of local chemical environment on the stability of intermediate species in oxidation-reduction reactions and the importance of mechanistic reaction pathways for defining possible reaction products and thermodynamic driving force. The discussion also includes examples of how detailed molecular/microscopic characterization of field samples has changed the way complex contaminant migration problems are conceptualized and modelled.

KeyWoRDs: radionuclides, interfacial reactivity, molecular-level analytical probes.

\section{Introduction}

MANY geochemical processes are governed by elementary reactions occurring at the mineralwater interface. Adsorption, ion diffusion, growth, dissolution, precipitation and electron transfer at mineral-water interfaces can change the composition of groundwater, control the geochemical cycling of elements and the migration and transformation of contaminants. Advances in spectroscopic and microscopic capabilities, synchrotron X-ray and neutron sources, and computational hardware and modelling methods have been essential components of the significant scientific progress made over the past few decades in understanding these complex dynamic processes. The molecular/microscopic-level understanding produced by these capabilities is now proving essential for the development of accurate conceptual models of radionuclide retention in the subsurface. As outlined below, new insights have emerged that highlight how reaction complexity at small scales has a substantial impact at large scales.

\section{Emerging paradigms}

In this section four examples of new research paradigms regarding the interfacial reactivity of mineral surfaces and heterogeneous natural materials are presented. The objective is to illustrate how advances in molecular/microscopic observations have transformed the way we think about and resolve practical problems in geochemistry.

\section{Surface catalysis of redox reactions: a different} perspective

For more than a decade it has been recognized that $\mathrm{Fe}(\mathrm{II})$ in different chemical forms can result in widely different levels of reduction of U(VI),

* E-mail: ar.felmy@pnl.gov

DOI: 10.1180/minmag.2011.075.4.2379 
$\mathrm{Np}(\mathrm{V})$, and $\mathrm{Tc}(\mathrm{VII})$ from their soluble and potentially environmentally mobile oxidized forms to their reduced and sparingly soluble tetravalent state (Grambow et al., 1996; Liger et al., 1999; Cui and Spahiu, 2002; Moyes et al., 2002; Nakata et al., 2002; Missana et al., 2003; O'Loughlin et al., 2003; Sani et al., 2004; Jeon et al., 2005; Scott et al., 2005; Senko et al., 2005; Jang et al., 2008; Regenspurg et al., 2009; Chakraborty et al., 2010; Descostes et al., 2010; Ilton et al., 2010). In particular, adsorption or structural incorporation of $\mathrm{Fe}(\mathrm{II})$ has been observed to enhance the reduction of actinides, pertechnetate and organics compared to aqueous $\mathrm{Fe}(\mathrm{II})$ (Klausen et al., 1995; Cui and Eriksen, 1996a,b; Charlet et al., 1998; Liger et al., 1999; Amonette et al., 2000; Pecher et al., 2002; Missana et al., 2003; Elsner et al., 2004; Fredrickson et al., 2004; Gregory et al., 2004; Ilton et al., 2004; Behrends and Van Cappellen, 2005; Jeon et al., 2005; Chun et al., 2006; Hofstetter et al., 2006; Zachara et al., 2007; Jang et al., 2008; Peretyazhko et al., 2008a,b).

One of the earliest examples specifically highlighting this phenomenon was the work of Liger et al. (1999), which demonstrated that $\mathrm{Fe}(\mathrm{II})$ in solution was largely ineffective as a reductant for $\mathrm{U}(\mathrm{VI})$ whereas the introduction of a solid phase, in this case hematite, appeared to result in rapid reduction of U(VI) to sparingly soluble U(IV). As a result of these and other studies, it has become widely accepted that sorbed $\mathrm{Fe}(\mathrm{II})$ generally has an enhanced thermodynamic reduction potential relative to aqueous $\mathrm{Fe}(\mathrm{II})$.

Although there is little doubt that the presence of certain mineral surfaces can accelerate radionuclide reduction rates, this enhanced reduction potential technically cannot be exclusively a thermodynamic potential because at equilibrium the total chemical potential of, for example, $\mathrm{Fe}$ (II) in the aqueous phase must be equal to the total chemical potential of $\mathrm{Fe}$ (II) at the mineral surface. Hence, at least at equilibrium, it is questionable if the increase in reduction potential is best described as thermodynamically driven. In non-equilibrium conditions the situation is even less clear. For example, when a mineral surface is introduced to a solution containing $\mathrm{Fe}$ (II)aq, Fe(II)aq can adsorb to the surface until equilibrium is reached. Until equilibrium, aqueous $\mathrm{Fe}(\mathrm{II})$ can be a stronger reducing agent than adsorbed $\mathrm{Fe}(\mathrm{II})$ from a thermodynamic perspective.

The chemical bonding environment of sorbed $\mathrm{Fe}(\mathrm{II})$ is of critical importance. For example,
Peretyazhko et al. (2008a,b) found that the reduction of $\mathrm{Tc}(\mathrm{VII})$ by $\mathrm{Fe}(\mathrm{II})$ adsorbed onto iron oxides was orders of magnitude faster than reduction by $\mathrm{Fe}$ (II) adsorbed at the same density onto various phyllosilicate surfaces and that the corresponding reduction reactions on corundum resulted in the formation of at least two different $\mathrm{Fe}(\mathrm{III})$-containing phases. This indicates that reduction by adsorbed Fe(II) is strongly affected by the substrate, which in turn suggests that coordination of $\mathrm{Fe}$ (II) to the surface could open reaction pathways not readily accessible in homogeneous systems. Viewed in this way, the mineral surface is seen to act as a catalyst or template, unlocking nucleation and growth of specific Fe(III) surface phases or reaction products.

With this line of reasoning in mind, it becomes important to consider the relative stabilities of different possible reaction products in any thermodynamic analysis of redox reactions involving $\mathrm{Fe}(\mathrm{II})$. To illustrate, we performed thermodynamic calculations (see Appendix A for details) to assess the impact of different possible $\mathrm{Fe}(\mathrm{III})$ reaction products on the reduction of $\mathrm{U}(\mathrm{VI}), \mathrm{Np}(\mathrm{V})$ and $\mathrm{Tc}(\mathrm{VII})$ by $\mathrm{Fe}(\mathrm{II})$. First consider the $\mathrm{Fe}(\mathrm{II}) / \mathrm{Fe}$ (III) homogeneous reaction:

$\mathrm{U}(\mathrm{VI})(\mathrm{aq})+\mathrm{Fe}(\mathrm{II})(\mathrm{aq}) \rightleftharpoons$

$$
\mathrm{Fe}(\mathrm{III})(\mathrm{aq})+\mathrm{UO}_{2}(\mathrm{am})
$$

Amorphous $\mathrm{UO}_{2}(\mathrm{am})$ was selected as a reaction product because its formation kinetics are much more rapid than crystalline $\mathrm{UO}_{2}(\mathrm{c})$ and the data of Liger et al. (1999) indicated very rapid kinetics. The (aq) symbols indicate that the full range of possible aqueous species for that element and oxidation state was considered in the calculations. For example, at lower $\mathrm{pH}$, reaction 1 is best represented as:

$$
\begin{aligned}
& \mathrm{UO}_{2}^{2+}+2 \mathrm{Fe}^{2+}+2 \mathrm{H}_{2} \mathrm{O} \underset{ }{2} \\
& 2 \mathrm{FeOH}^{2+}+\mathrm{UO}_{2}(\mathrm{am})+2 \mathrm{H}^{+}
\end{aligned}
$$

At higher $\mathrm{pH}$ other hydrolysis species of $\mathrm{U}(\mathrm{VI})$, $\mathrm{Fe}(\mathrm{II})$ and $\mathrm{Fe}(\mathrm{III})$ are important. These species are included in the thermodynamic model (see Appendix). We then calculated the total aqueous uranium concentration, via overall reaction 1 , that remained in solution as a function of $\mathrm{pH}$ while only allowing the formation of aqueous Fe(III). In this simulation we used the total initial aqueous $\mathrm{Fe}(\mathrm{II})$ and $\mathrm{U}(\mathrm{VI})$ concentrations in Liger et al. (1999). The results are shown in Fig. 1 and labelled 'aqueous $\mathrm{Fe}$ (III) only'. Under these conditions aqueous $\mathrm{Fe}(\mathrm{II})$ can only reduce aqueous $\mathrm{U}(\mathrm{VI})$ to $\mathrm{UO}_{2}(\mathrm{am})$ at $\mathrm{pH}$ values $>8$. 
However, if more stable $\mathrm{Fe}(\mathrm{III})$ reaction products are allowed to form, the $\mathrm{pH}$ range over which $\mathrm{U}(\mathrm{VI})$ reduction is thermodynamically possible expands considerably. For example if hematite is allowed to form via the overall reaction:

$\mathrm{U}(\mathrm{VI})(\mathrm{aq})+2 \mathrm{Fe}(\mathrm{II})(\mathrm{aq}) \rightleftharpoons$

$$
\mathrm{UO}_{2}(\mathrm{am})+\mathrm{Fe}_{2} \mathrm{O}_{3} \text { (hematite) }
$$

it becomes thermodynamically possible to reduce $\mathrm{U}(\mathrm{VI})$ to $\mathrm{U}(\mathrm{IV})$ at $\mathrm{pH}$ values just above 6 (see Fig. 1; hematite formation allowed). The calculations illustrate that the free energy of the Fe(III) reaction products is a key factor in determining the range of conditions under which it is possible to reduce $\mathrm{U}(\mathrm{VI})$ by $\mathrm{Fe}(\mathrm{II})$ and that adsorption of aqueous $\mathrm{Fe}(\mathrm{II})$ onto the ferric oxide surface is probably a key step which is necessary to open up these reaction pathways. Liger et al. (1999) found that $\mathrm{U}(\mathrm{VI})$ was only reduced at or above $\mathrm{pH}$ 7.5. Interestingly, $\mathrm{pH} 7.5$ is the exact $\mathrm{pH}$ where $\mathrm{U}(\mathrm{VI})$ should be reduced to U(IV) under these experimental conditions if the net reduction reaction involves the formation of $\mathrm{Fe}(\mathrm{OH})_{3}(\mathrm{am})$ or 2-line ferrihydrite (2LF) via a reaction similar to reaction (3). This at least suggests the possibility that the introduction of hematite resulted in the formation of $\mathrm{Fe}(\mathrm{OH})_{3}(\mathrm{am})$ as a reaction product or at least an $\mathrm{Fe}(\mathrm{III})$-containing reaction product with a similar chemical potential.

Modelling the reduction of other redox active radionuclides by $\mathrm{Fe}(\mathrm{II})$ such as $\mathrm{Tc}(\mathrm{VII})$ to $\mathrm{Tc}(\mathrm{IV})$, $\mathrm{Pu}(\mathrm{IV})$ to $\mathrm{Pu}(\mathrm{III})$, and $\mathrm{Np}(\mathrm{V})$ to $\mathrm{Np}(\mathrm{IV})$ demonstrates that the type of $\mathrm{Fe}(\mathrm{III})$ reaction product

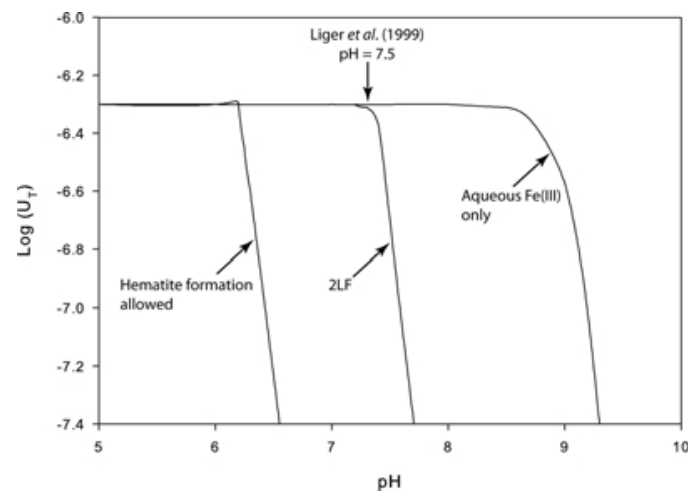

Fig. 1. Calculated U(VI) concentrations in $0.1 \mathrm{M} \mathrm{NaNO}_{3}$ concentrations allowing the formation of $\mathrm{UO}_{2}(\mathrm{am})$ and an initial total concentrations of $1.6 \times 10^{-4} \mathrm{M}$ for $\mathrm{Fe}(\mathrm{II})$ and $5 \times 10^{-7} \mathrm{M}$ for $\mathrm{U}(\mathrm{VI})$. The symbol $2 \mathrm{LF}$ represents use of a solubility product for 2-line ferrihydrite given by Stefansson et al. (2007). formed also has a large impact on the $\mathrm{pH}$ range over which the reaction occurs. For example, in common with $\mathrm{U}(\mathrm{VI})$, the $\mathrm{pH}$ range over which $\mathrm{Np}(\mathrm{V})$ can be reduced to sparingly soluble $\mathrm{NpO}_{2}(\mathrm{am})$ by $\mathrm{Fe}(\mathrm{II})$ initially only in the aqueous phase is a strong function of the free energy of the Fe(III) reaction product (Fig. $2 a$ ). Correspondingly, reduction of $\mathrm{Np}(\mathrm{V})$ by $\mathrm{Fe}(\mathrm{II})$ initially only present in a solid phase, in this case magnetite, is also affected by the $\mathrm{Fe}$ (III) reaction product (Fig. 2b). If the calculations only permit $\mathrm{Fe}(\mathrm{OH})_{3}(\mathrm{am})$ to form, no reduction occurs because there is insufficient free energy to drive the reaction. If, however, the Fe(III) structural analogue to magnetite, maghemite, is allowed to form, there is sufficient free energy to reduce $\mathrm{Np}(\mathrm{V})$ to $\mathrm{NpO}_{2}(\mathrm{am})$ across a wide $\mathrm{pH}$ range.

Because realistic experiments simulating the redox behaviour of radionuclides in the
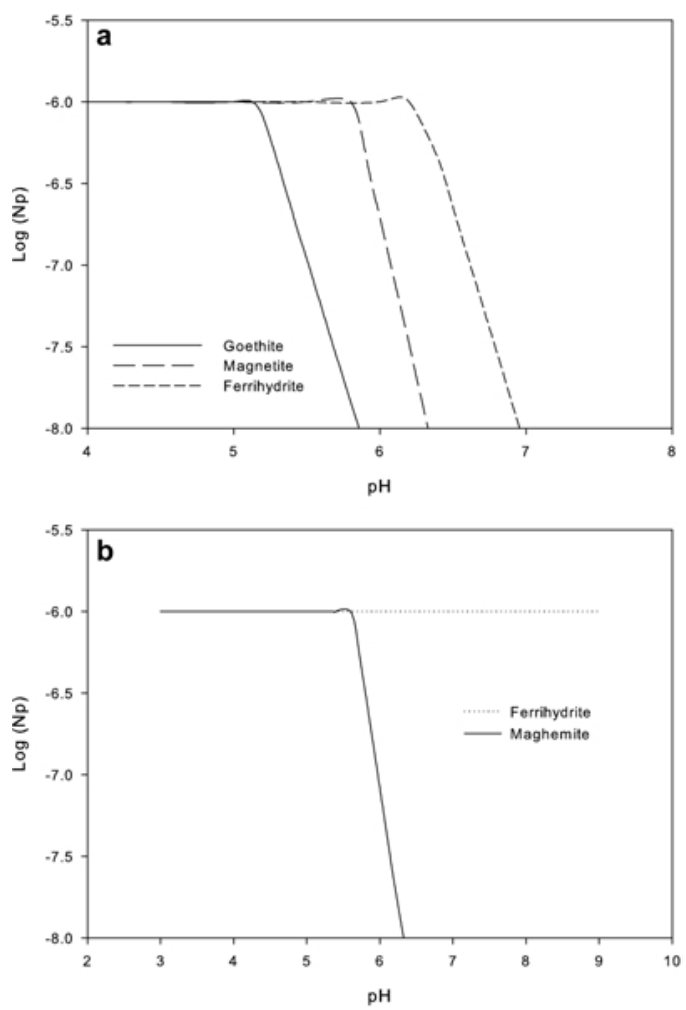

FIG. 2. Reduction of $\mathrm{Np}(\mathrm{V})$ to $\mathrm{NpO}_{2}(\mathrm{am})$ by $\mathrm{Fe}(\mathrm{II})$ to form different $\mathrm{Fe}$ (III) reaction products. (a) The impact of allowing different ferric oxide solids to form. Reaction conditions are: $\mathrm{Fe}(\mathrm{II})=10 \mu \mathrm{M}, \mathrm{Np}(\mathrm{V})=1$ $\mu$ m. (b) The impact of adding Fe(II) as an initial solid (magnetite) without any initial aqueous $\mathrm{Fe}(\mathrm{II})$. 
environment commonly involve very low concentrations of the radionuclide of interest, the Fe(III) reaction product is usually produced in correspondingly miniscule concentrations, making it difficult to identify. Furthermore, understanding the microscopic- or molecular-scale factors that control the nucleation and growth of specific types of $\mathrm{Fe}(\mathrm{III})$ products constitutes a substantial challenge for future research. A combination of experimentation using both electron conducting and non-conducting surfaces, the application of spectroscopy and microscopy and theoretical modelling will be required to make significant progress in these two critical areas.

\section{Electron conduction: a mechanism for long-range reaction on mineral surfaces}

One of the fundamental concepts in geochemistry is that evaluating the reactivity of individual surface sites is the key to developing better predictive geochemical models. For example, this concept forms the basis of geochemical models such as the MUSIC model (Hiemstra and Van Riemsdijk, 2006; Rahnemaie et al., 2006a,b; Hiemstra et al., 2007; Hiemstra and Van Riemsdijk, 2009; Ridley et al., 2009; among many others) where individual molecular surface groups with different surface coordination are given explicit protonation or complexation constants. Although this local molecular species concept has gone a long way in helping to interpret many geochemical phenomena at mineral-water interfaces, it has recently become apparent that in some important cases sites cannot be separated; reactions at one surface site can influence the reactivity of distal sites either on the same or even on different crystallographic surfaces.

As a case in point, it has been discovered that interfacial electron transfer reactions at one surface of an electrically semiconducting mineral can couple with those at other surfaces by bulk electrical conduction (Yanina and Rosso, 2008). For Fe(III)-(oxyhydr)oxides in Fe(II)bearing aqueous solution, this linkage produces interfacial phenomena that are distinct from those that are possible at insulating mineral surfaces, including reductive dissolution of higher-energy surface sites coupled to formation of lowerenergy surfaces by oxidative precipitation and growth, linked by electron conduction through the bulk solid (see Fig. 3). In fact, it has been hypothesized that such processes may be responsible for the complete reconstruction of goethite in $\mathrm{Fe}(\mathrm{II})$-bearing aqueous solutions under environmentally relevant conditions (Handler et al., 2009). How such processes might affect the fate and transport of redox sensitive radionuclides such as $\mathrm{U}, \mathrm{Np}, \mathrm{Tc}$ and $\mathrm{Pu}$ in the environment is of obvious interest.

\section{The formation of intermediate oxidation states: a key to determining reaction rates}

One of the most important research challenges in low-temperature geochemistry is determining reaction kinetics. A key aspect is the possible formation of transient reaction intermediates whose stabilities relative to final products can either facilitate or hinder an overall reaction. In the case of polyvalent radionuclides such as $U$, $\mathrm{Pu}, \mathrm{Np}$ and $\mathrm{Tc}$, redox reactions can involve multiple electron transfer steps, a fact that implies temporary formation of short- or long-lived intermediate oxidation states.

For example, the reduction of U(VI) to U(IV) requires the transfer of two electrons. Until recently, the intermediate $\mathrm{U}(\mathrm{V})$ had never been documented to occur in inorganic systems where $\mathrm{Fe}(\mathrm{II})$ is the reductant. This is the expectation as $\mathrm{U}(\mathrm{V})$ has a small stability field in water, and it is uncommon, although not entirely unknown, in minerals.

Surprisingly, Ilton and colleagues discovered the presence of $U(V)$ at the near-surface of annite and magnetite under reducing conditions where U(IV) was expected to form (Ilton et al., 2005, 2010). The question is, why does $\mathrm{U}(\mathrm{V})$ persist in these cases? Ilton et al. (2010) showed, using combined XAFS and XPS measurements, that U(V) was incorporated into secondary precipitates in the uranate rather than uranyl coordination scheme. Furthermore, ab initio molecular cluster modelling of $\mathrm{U}(\mathrm{VI})$ reduction by $\mathrm{Fe}(\mathrm{II})$ indicates that uranate coordination tends to stabilize $\mathrm{U}(\mathrm{V})$ relative to $\mathrm{U}(\mathrm{VI})$, and that $\mathrm{U}(\mathrm{IV})$ is strongly stabilized by 8 -fold coordination. These results suggest the interesting possibility that reaction mechanisms favouring uranate coordination as an outcome can reduce the overall reduction rate of $\mathrm{U}(\mathrm{VI})$ to $\mathrm{U}(\mathrm{IV})$ by increasing the lifetime of and accumulating $\mathrm{U}(\mathrm{V})$ species. Reduction rates of U(VI) to U(IV) are therefore likely to be highly dependent on the coordination environment of uranium.

Detecting reaction intermediates and defining their coordination environment is therefore a key to understanding overall redox rates for polyvalent metal ions. Unfortunately, this remains a 


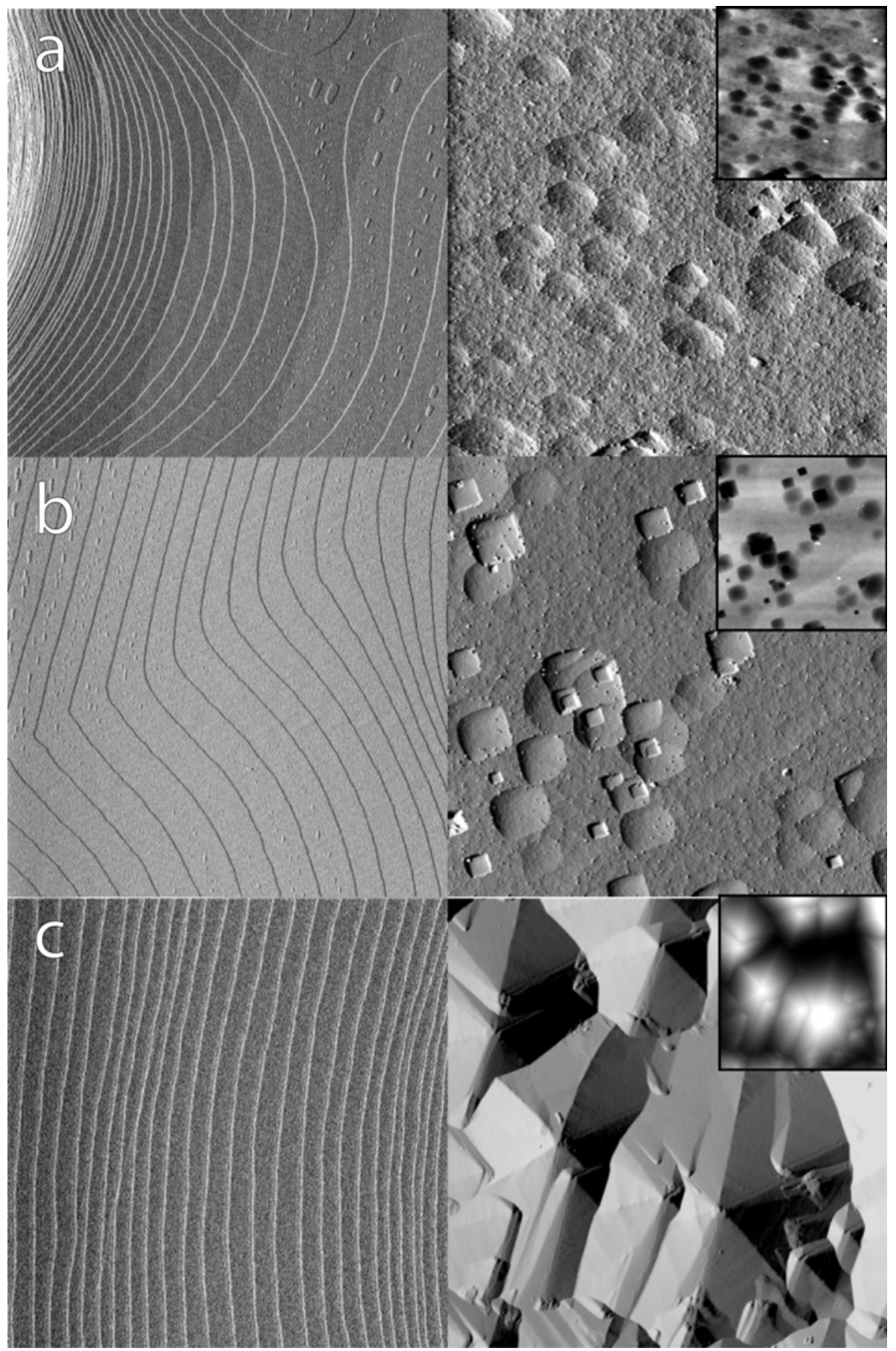

FIG. 3. Atomic force microscopy (AFM) images of hematite surfaces before and after reaction showing the dissolution of the (012), and (112) surfaces and the simultaneous growth of the (001) surface. Reaction conditions $12 \mathrm{~h}$ at $75^{\circ} \mathrm{C}, \mathrm{pH}(2-3)$ in $1 \mathrm{~mm} \mathrm{Fe}(\mathrm{II})$ and $10 \mathrm{~mm}$ oxalate: (a) (012) hematite surface; (b) (112) hematite surface; (c) (001) hematite surface (from Yanina and Rosso, 2008; reprinted with permission from AAAS). 
difficult challenge because of the typical transience of such species or their presence at very low concentrations.

\section{Molecular/microscopic characterization of field samples: developing an accurate conceptual model}

The characterization of complex natural samples from field sites has been a research challenge since the beginning of geochemistry and it is likely to remain so for many years despite the increasing availability of sophisticated laboratory instrumentation and computation. One can nonetheless find many examples of how molecular and microscopic characterization of field samples has been a critical factor in estimating past and predicting future radionuclide migration behaviour. Here we specifically highlight three contaminated sites at the U.S. Department of Energy's Hanford nuclear reservation in Washington State, USA. These examples were selected in part because even though they are from the same geological setting, the mechanisms of radionuclide retention or release are entirely different at each site. Identifying and differentiating these mechanisms has been a key aspect in developing new conceptual models of radionuclide migration, models that, in turn, have provided focus for macroscopic experimental and modelling programs.

\section{${ }^{137}$ Cs migration near the Hanford S-SX tank farm}

Caesium-137 is produced by fission of ${ }^{238} U$ and is a common contaminant in nuclear-weapons production. At Hanford over 1 million curies of ${ }^{137} \mathrm{Cs}$ have leaked from single-shell storage tanks (SSTs) into coarse-textured, relatively unweathered sediments of the Hanford Formation. At Hanford's S-SX tank farm, the leaking highlevel waste (HLW) solution was a high temperature $\left(>70^{\circ} \mathrm{C}\right)$, highly alkaline solution with a high $\mathrm{Na}^{+}$concentration. Although in most cases the ${ }^{137} \mathrm{Cs}$ was found to be sorbed as $\mathrm{Cs}^{+}$by the micaceous component of the sediment, limiting vertical migration to distances of 6-20 m, in other cases it experienced relatively little chemical retardation and migrated deep into the subsurface. These findings produced concerns about whether the ${ }^{137} \mathrm{Cs}$ would ultimately migrate to groundwater at $\sim 30-40 \mathrm{~m}$ depth (McKinley et al., 2001).

The microscopic form of the $\mathrm{Cs}$ in the sediments is the most important characteristic with respect to its potential for future transport because it controls its ability to react with groundwater or infiltrating meteoric recharge. $\mathrm{X}$-ray microprobe measurements of $\mathrm{Cs}^{+}$sorbed to micaceous particles from Hanford sediments showed $\mathrm{Cs}^{+}$bound in a complex intra-particle distribution, including localized deposits at select edge regions, at the particle periphery and within internal channels running parallel to the basal plane (Fig. 4). The observations were consistent with size-selective ion exchange of $\mathrm{Cs}^{+}$with cations native to the interlayer domain, such as $\mathrm{K}^{+}$. Consequently, macroscopic Cs-retention behaviour based on this mineralogically specific heterogeneous intra-particle binding mechanism turned out to be amenable to description using a two-site ion-exchange model linked to a slabdiffusion transport model. The parameterization and application of this model in a series of coupled macroscopic and microscopic studies (McKinley et al., 2001; Zachara et al., 2002; Liu et al., 2003) of contaminated and uncontaminated sediments revealed that cases where expedited migration of ${ }^{137} \mathrm{Cs}$ was observed could be explained by the competitive effect of the massive $\mathrm{Na}^{+}$concentration, accentuated by the displacement of $\mathrm{K}^{+}$from the sediments at the leading edge of the HLW front. The discovery of the microscopic mechanism of Cs binding was therefore fundamental to resolving the issue of $\mathrm{Cs}^{+}$migration beneath the SSTs.

\section{Uranium at the $B-B X$ tank farm}

As the second Hanford example, in 1951 an inter-tank pipeline ruptured in tank BX-102 and $\sim 7000 \mathrm{~kg}$ of uranium in an alkaline sodium carbonate, nitrate, phosphate solution was released to the ground (McKinley et al., 2006). Characterization of the contaminated sediments with various molecular-level and microscopic probes (Catalano et al., 2004; Liu et al., 2004; Wang et al., 2005b; Liu et al., 2006; McKinley et al., 2006; Ilton et al., 2008) revealed that the uranium was present as $\mathrm{U}(\mathrm{VI})$ and occurred as micron-sized uranyl silicate crystallites that grew in microfractures in granitic clasts (Fig. 5).

Uranium release to solution from the sediments was found to be kinetically complex. A model based on coupled rates of Na-boltwoodite dissolution with uranyl diffusion rates in microfractures was found to be required to predict the overall release behaviour accurately. This new conceptual model was different from the model used to resolve the $\mathrm{Cs}^{+}$migration issue at the S-SX tank farm, and could not have been 


\section{Muscovite Section}
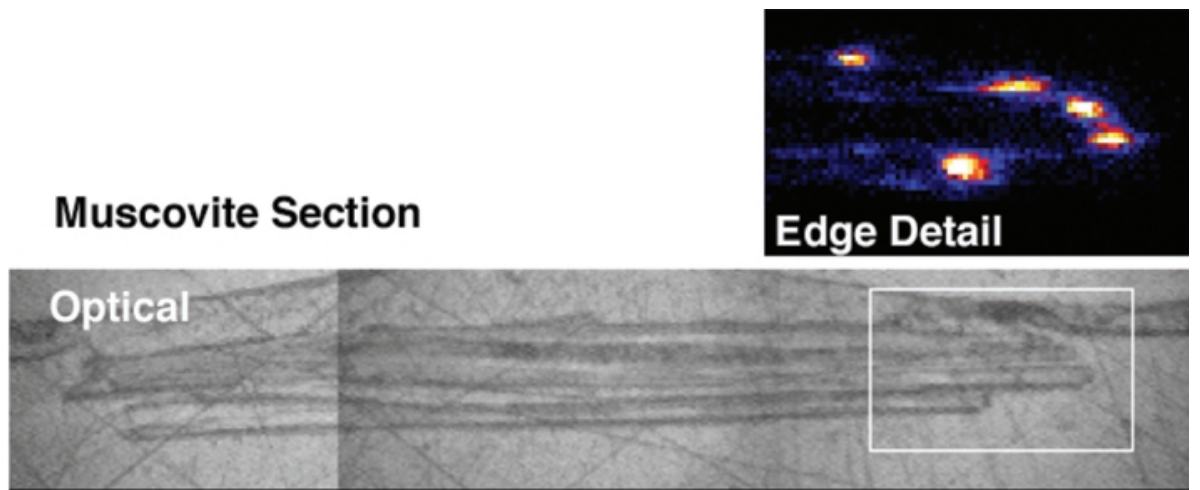

\section{Normal Brightness}
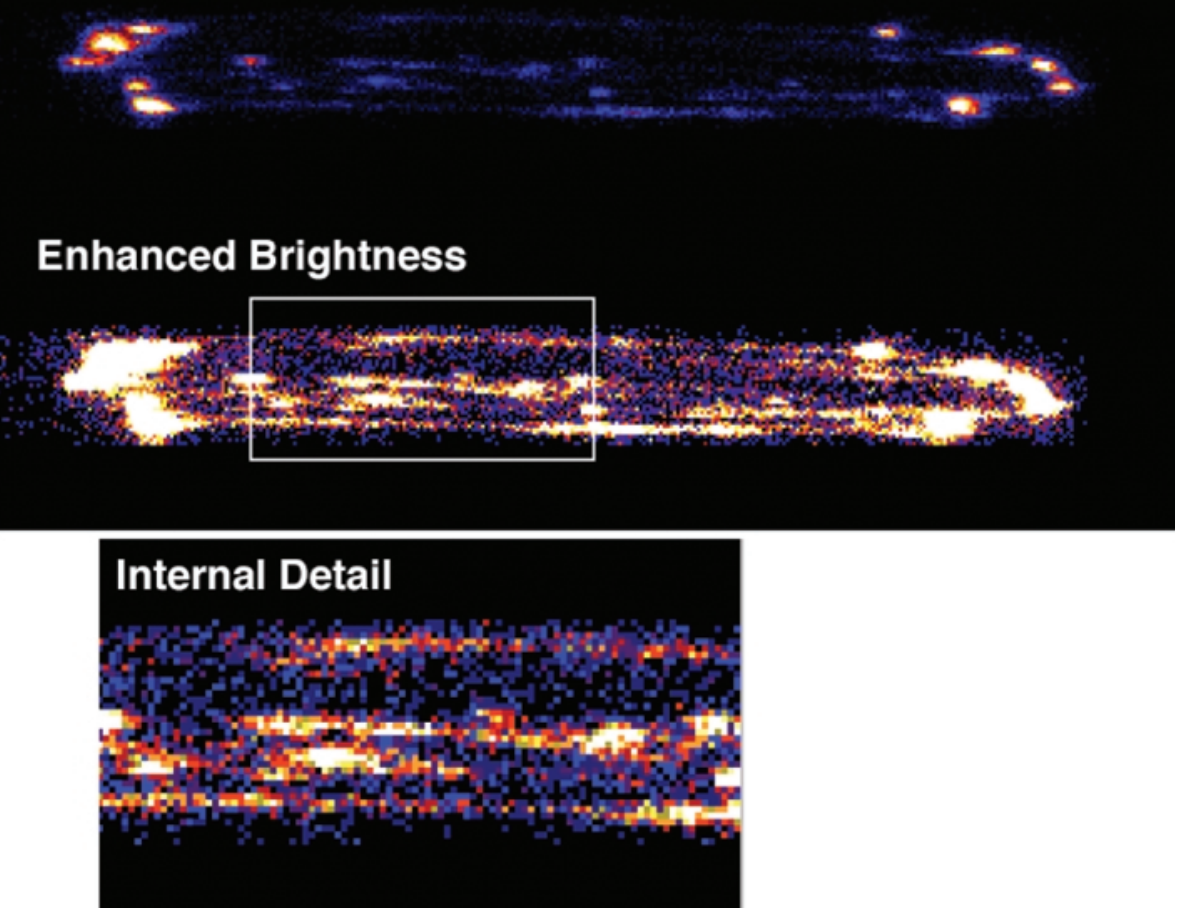

Fig. 4. X-ray microprobe images of a $\mathrm{Cs}^{+}$-treated muscovite flake showing the ${ }^{137} \mathrm{Cs}^{+}$distribution on edges and on intraparticle channels in the mica basal plane (reprinted from Liu et al. (2003) with permission from Elsevier).

formulated without molecular/microscopic characterization of uranium speciation and physical residence in the sediments.

\section{Area process ponds}

As the final example, between 1943 and 1975, unirradiated fuel-rod waste consisting of approximately $58,000 \mathrm{~kg}$ of uranium and $238,000 \mathrm{~kg}$ of $\mathrm{Cu}$, along with high concentrations of fluoride, nitrate and aluminate, were disposed to the $300 \mathrm{~A}$ north and south processing ponds. The $300 \mathrm{~A}$ processing ponds were $\sim 100 \mathrm{~m}$ west of the Columbia River at the south end of the Hanford site. Despite the excavation of the top several metres of sediment, a plume of uraniumcontaminated groundwater remains to this day. As a result, the final remediation of the site must rely on the evaluation of various modelling 


\section{A. R. FELMY ET AL.}

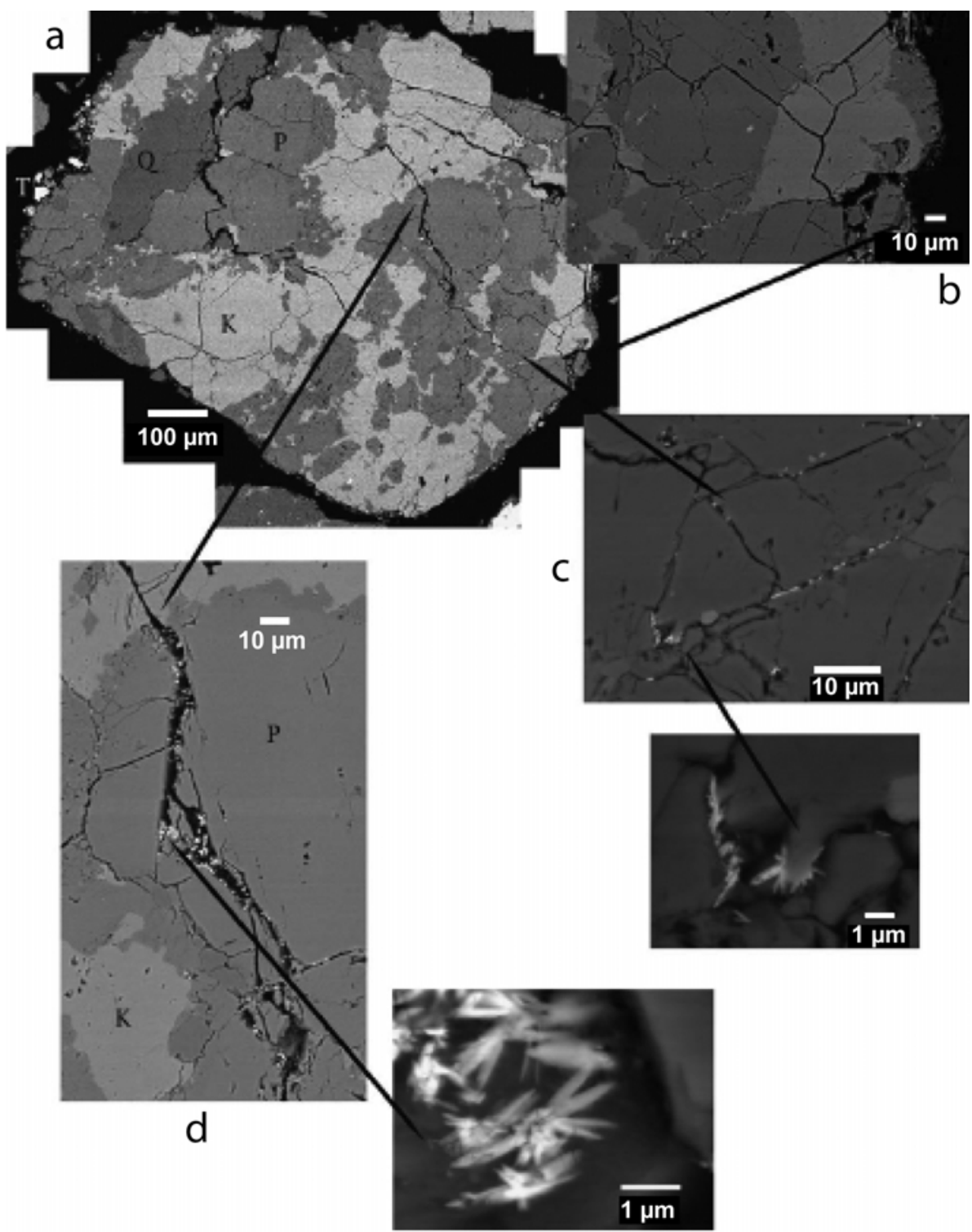

FIG. 5. Backscattered electron images of uranyl silicate within microfractures of a single granitic clast, in thin section. (a) Photomosaic of full clast; $(b-d)$ uranyl silicate precipitates in fractures progressively further from the clast surface. Abbreviations are: Q, quartz; P, plagioclase; K, potassium feldspar and T, titanomagnetite. Successive images show details of the uranyl silicate habit. The fine uranyl silicate crystals occupy microfractures and are associated with plagioclase (reprinted from McKinley et al. (2006) with permission from Elsevier).

scenarios that predict the fate and transport of $U$, coupled with conceptual models that incorporate a fundamental understanding of uranium geochemistry. In a series of molecular/microscopic investigations (Wang et al., 2005a; Zachara, 2005; Catalano et al., 2006; Arai et al., 2007;
Stubbs et al., 2009) it was found that the chemical form of uranium in the sediments varied with depth, from discrete uranium phosphate phases and uranium substituted calcite in the upper vadose-zone sediments to $\mathrm{U}(\mathrm{VI})$ adsorption complexes deeper in the vadose zone (Fig. 6). 


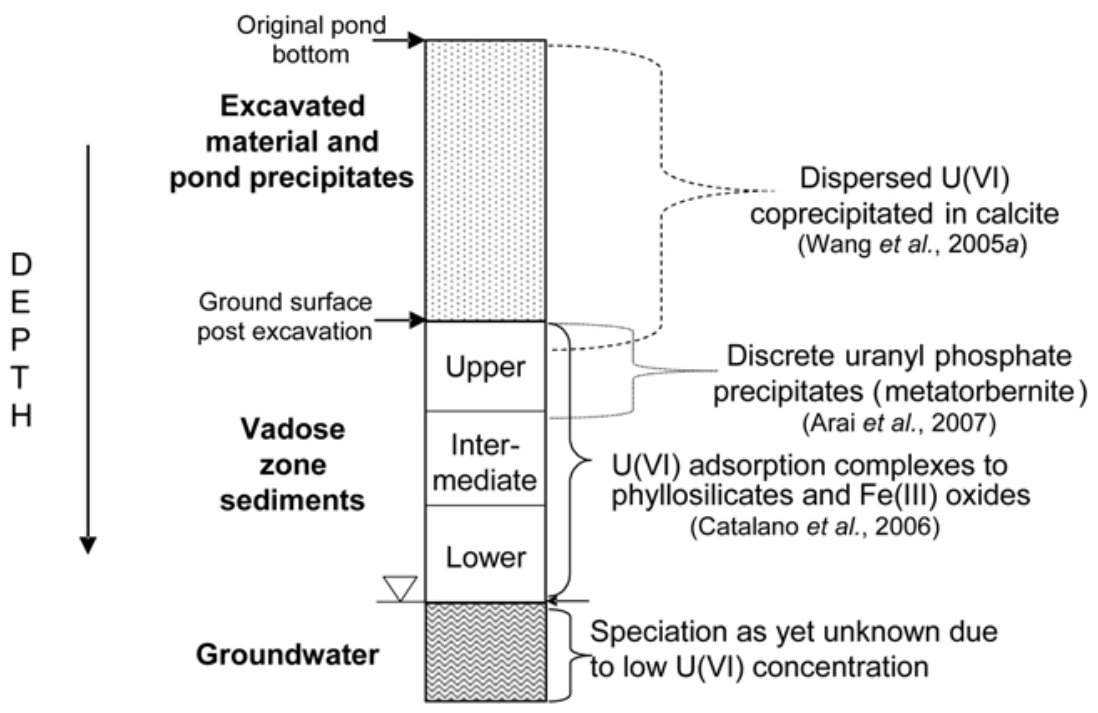

FIG. 6. Geochemical speciation beneath the 300 area process ponds.

The precipitates often exist within microporous domains of grain coatings resulting from sediment-waste reaction, that slow the rate of exchange of $\mathrm{U}(\mathrm{VI}) \mathrm{aq}$ and dissolution-promoting $\mathrm{HCO}_{3}^{-}$with pore waters. As was the case in the first two examples, these fundamental insights into the geochemical behaviour of uranium at 300 A are currently being combined with a new generation of reactive transport models that include the influence of variable groundwater level resulting from changes in Columbia River flow, on uranium migration.

The three Hanford-specific examples mentioned illustrate the complex relationships between chemical speciation and reaction microenvironment. Detailed molecular/microscopic characterization of field samples is consequently essential for unravelling field-scale behaviour that often appears to be kinetically controlled and conceptual models of radionuclide retention and transport must integrate this knowledge with appropriate microscopic and macroscopic transport behaviours for realistic system descriptions.

\section{Summary and conclusions}

Over the past two decades advances in molecular and microscopic analysis capabilities have changed the way geochemical problems are approached. This new insight has led to the discovery of previously unknown mechanisms of mineral reactivity, the ability to identify reaction intermediates that may control the kinetics of geochemical reactions and the ability to develop accurate conceptual models of complex subsurface reactivity that form the basis of reliable macroscopic reactive transport models. In many cases, however, the impact of these new paradigms has yet to be fully realized. Molecular/microscopic analysis of field samples is still viewed as novel and has not yet become a standard practice. The impact of bulk mineral electron conduction on radionuclide redox reactions at semiconducting mineral surfaces has not been examined in any significant detail. The difficulty of analysing reaction products and intermediates at low concentration in complex environmental samples still limits our ability to develop accurate predictive models. As a result, these areas represent excellent opportunities for future research.

\section{Acknowledgements}

This work was partially funded by the Geosciences Research Program of the Office of Basic Energy Sciences (BES), US Department of Energy. This work was also partially supported by the US Department of Energy's Office of Biological and Environmental Research, as part of the Subsurface Biogeochemical Research (SBR) Science Focus Area (SFA) at the Pacific 
Northwest National Laboratory. A portion of this research was performed using EMSL, a national scientific user facility sponsored by the US Department of Energy's Office of Biological and Environmental Research and located at the Pacific Northwest National Laboratory.

\section{References}

Amonette, J.E., Workman, D.J., Kennedy, D.W., Fruchter, J.S. and Gorby, Y.A. (2000) Dechlorination of carbon tetrachloride by $\mathrm{Fe}(\mathrm{II})$ associated with goethite. Environmental Science \& Technology, 34, 4606-4613.

Arai, Y., Marcus, M.K., Tamura, N., Davis, J.A. and Zachara, J.M. (2007) Spectroscopic evidence for uranium bearing precipitates in vadose zone sediments at the Hanford 300-area site. Environmental Science \& Technology, 41, 4633-4639.

Behrends, T. and Van Cappellen, P. (2005) Competition between enzymatic and abiotic reduction of uranium(VI) under iron reducing conditions. Chemical Geology, 220, 315-327.

Catalano, J.G., Heald, S.M., Zachara, J.M. and Brown, G.E., Jr. (2004) Spectroscopic and diffraction study of uranium speciation in contaminated vadose zone sediments from the Hanford Site, Washington State. Environmental Science \& Technology, 38, $2822-2828$.

Catalano, J.G., McKinley, J.P., Zachara, J.M., Smith, S.C. and Brown, G.E., Jr. (2006) Changes in uranium speciation through a depth sequence of contaminated Hanford sediments. Environmental Science \& Technology, 40, 2517-2524.

Chakraborty, S., Favre, F., Banerjee, D., Scheinost, A.C., Mullet, M., Ehrhardt, J.J., Brendle, J., Vidal, L. and Charlet, L. (2010) U(VI) Sorption and reduction by Fe(II) sorbed on montmorillonite. Environmental Science \& Technology, 44, 3779-3785.

Charlet, L., Silvester, E. and Liger, E. (1998) Ncompound reduction and actinide immobilisation in surficial fluids by $\mathrm{Fe}(\mathrm{II})$ : the surface $\equiv \mathrm{Fe}^{\mathrm{III}} \mathrm{OFe}^{\mathrm{II}} \mathrm{OH}^{\circ}$ species, as major reductant. Chemical Geology, 151, $85-93$.

Chun, C.L., Penn, R.L. and Arnold, W.A. (2006) Kinetic and microscopic studies of reductive transformations of organic contaminants on goethite. Environmental Science \& Technology, 40, 3299-3304.

Cui, D.Q. and Eriksen, T.E. (1996a) Reduction of pertechnetate by ferrous iron in solution: influence of sorbed and precipitated $\mathrm{Fe}(\mathrm{II})$. Environmental Science \& Technology, 30, 2259-2262.

Cui, D.Q. and Eriksen, T.E. (1996b) Reduction of pertechnetate in solution by heterogeneous electron transfer from $\mathrm{Fe}(\mathrm{II})$-containing geological material. Environmental Science \& Technology, 30,
$2263-2269$

Cui, D.Q. and Spahiu, K. (2002) The reduction of U(VI) on corroded iron under anoxic conditions. Radiochimica Acta, 90, 623-628.

Descostes, M., Schlegel, M.L., Eglizaud, N., Descamps, F., Miserque, F. and Simoni, E. (2010) Uptake of uranium and trace elements in pyrite $\left(\mathrm{FeS}_{2}\right)$ suspensions. Geochimica et Cosmochimica Acta, 74, 1551-1562.

Elsner, M., Schwarzenbach, R.P. and Haderlein, S.B. (2004) Reactivity of Fe(II)-bearing minerals toward reductive transformation of organic contaminants. Environmental Science \& Technology, 38, 799-807.

Felmy, A. (1990) GMIN: a computerized chemical equilibrium model using a constrained minimization of the gibbs free energy. PNNL-7281, Pacific Northwest National Laboratory, Richland, WA.

Felmy, A.R. and Rai, D. (1999) Application of Pitzer's equations for modeling the aqueous thermodynamics of actinide species in natural waters: a review. Journal of Solution Chemistry, 28, 533-553.

Fredrickson, J.K., Zachara, J.M., Kennedy, D.W., Kukkadapu, R.K., McKinley, J.P., Heald, S.M., Liu, C.X. and Plymale, A.E. (2004) Reduction of $\mathrm{TcO}_{4}^{-}$by sediment-associated biogenic $\mathrm{Fe}(\mathrm{II})$. Geochimica et Cosmochimica Acta, 68, 3171-3187.

Grambow, B., Smailos, E., Geckeis, H., Muller, R. and Hentschel, H. (1996) Sorption and reduction of uranium(VI) on iron corrosion products under reducing saline conditions. Radiochimica Acta, 74, $149-154$.

Gregory, K.B., Larese-Casanova, P., Parkin, G.F. and Scherer, M.M. (2004) Abiotic transformation of hexahydro-1,3,5-trinitro-1,3,5-triazine by fell bound to magnetite. Environmental Science \& Technology, 38, 1408-1414.

Guillaumont, R. and Mompean, F.J. (2003) Update on the chemical thermodynamics of uranium, neptunium, plutonium, americium and technetium. Elsevier, Amsterdam.

Handler, R.M., Beard, B.L., Johnson, C.M. and Scherer, M.M. (2009) Atom exchange between aqueous $\mathrm{Fe}(\mathrm{II})$ and goethite: an $\mathrm{Fe}$ isotope tracer study. Environmental Science \& Technology, 43, 1102-1107.

Hiemstra, T. and Van Riemsdijk, W.H. (2006) On the relationship between charge distribution, surface hydration, and the structure of the interface of metal hydroxides. Journal of Colloid and Interface Science, 301, 1-18.

Hiemstra, T. and Van Riemsdijk, W.H. (2009) A surface structural model for ferrihydrite I: sites related to primary charge, molar mass, and mass density. Geochimica et Cosmochimica Acta, 73, 4423-4436.

Hiemstra, T., Barnett, M.O. and van Riemsdijk, W.H. (2007) Interaction of silicic acid with goethite. 
Journal of Colloid and Interface Science, 310, 8-17.

Hofstetter, T.B., Neumann, A. and Schwarzenbach, R.P. (2006) Reduction of nitroaromatic compounds by $\mathrm{Fe}$ (II) species associated with iron-rich smectites. Environmental Science \& Technology, 40, 235-242.

Ilton, E.S., Haiduc, A., Moses, C.O., Heald, S.M., Elbert, D.C. and Veblen, D.R. (2004) Heterogeneous reduction of uranyl by micas: crystal chemical and solution controls. Geochimica et Cosmochimica Acta, 68, 2417-2435.

Ilton, E.S., Haiduc, A., Cahill, C.L. and Felmy, A.R. (2005) Mica surfaces stabilize pentavalent uranium. Inorganic Chemistry, 44, 2986-2988.

Ilton, E.S., Qafoku, N.P., Liu, C.X., Moore, D.A. and Zachara, J.M. (2008) Advective removal of intraparticle uranium from contaminated vadose zone sediments, Hanford, US. Environmental Science \& Technology, 42, 1565-1571.

Ilton, E.S., Boily, J.F., Buck, E.C., Skomurski, F.N., Rosso, K.M., Cahill, C.L., Bargar, J.R. and Felmy, A.R. (2010) Influence of dynamical conditions on the reduction of U-VI at the magnetite-solution interface. Environmental Science \& Technology, 44, $170-176$.

Jang, J.H., Dempsey, B.A. and Burgos, W.D. (2008) Reduction of $\mathrm{U}(\mathrm{VI})$ by $\mathrm{Fe}(\mathrm{II})$ in the presence of hydrous ferric oxide and hematite: effects of solid transformation, surface coverage, and humic acid. Water Research, 42, 2269-2277.

Jeon, B.H., Dempsey, B.A., Burgos, W.D., Barnett, M.O. and Roden, E.E. (2005) Chemical reduction of $\mathrm{U}(\mathrm{VI})$ by $\mathrm{Fe}(\mathrm{II})$ at the solid-water interface using natural and synthetic Fe(III) oxides. Environmental Science \& Technology, 39, 5642-5649.

Klausen, J., Trober, S.P., Haderlein, S.B. and Schwarzenbach, R.P. (1995) Reduction of substituted nitrobenzenes by $\mathrm{Fe}$ (II) in aqueous mineral suspensions. Environmental Science \& Technology, 29, 2396-2404.

Lemire, R.J., Fuger, J., Nitsche, H., Potter, P., Rand, M.H., Rydberg, J., Spahiu, K., Sullivan, J.C., Ullman, W.J., Vitorge, P. and Wanner, H. (editors) (2001) Chemical thermodynamics of neptunium and plutonium. Elsevier, Amsterdam, $845 \mathrm{pp}$.

Liger, E., Charlet, L. and Van Cappellen, P. (1999) Surface catalysis of uranium(VI) reduction by iron(II). Geochimica et Cosmochimica Acta, 63, 2939-2955.

Liu, C.X., Zachara, J.M., Smith, S.C., McKinley, J.P. and Ainsworth, C.C. (2003) Desorption kinetics of radiocesium from subsurface sediments at Hanford Site, USA. Geochimica et Cosmochimica Acta, 67, 2893-2912.

Liu, C.X., Zachara, J.M., Qafoku, O., McKinley, J.P., Heald, S.M. and Wang, Z.M. (2004) Dissolution of uranyl microprecipitates in subsurface sediments at
Hanford Site, USA. Geochimica et Cosmochimica Acta, 68, 4519-4537.

Liu, C.X., Zachara, J.M., Yantasee, W., Majors, P.D. and McKinley, J.P. (2006) Microscopic reactive diffusion of uranium in the contaminated sediments at Hanford, United States. Water Resources Research, 42, http://dx.doi.org/10.1029/ 2006WR005031.

Martell, A.E. and Smith, R.M. (2003) NIST critically selected stability constants of metal complexes. NIST Standard Reference Database 46 Version 7.0. National Institute of Standards and Technology, Gaithersburg, MD, USA.

McKinley, J.P., Zeissler, C.J., Zachara, J.M., Serne, R.J., Lindstrom, R.M., Schaef, H.T. and Orr, R.D. (2001) Distribution and retention of Cs-137 in sediments at the Hanford Site, Washington. Environmental Science \& Technology, 35, 3433-3441.

McKinley, J.P., Zachara, J.M., Liu, C.X., Heald, S.C., Prenitzer, B.I. and Kempshall, B.W. (2006) Microscale controls on the fate of contaminant uranium in the vadose zone, Hanford Site, Washington. Geochimica et Cosmochimica Acta, 70, 1873-1887.

Missana, T., Maffiotte, U. and Garcia-Gutierrez, M. (2003) Surface reactions kinetics between nanocrystalline magnetite and uranyl. Journal of Colloid and Interface Science, 261, 154-160.

Moyes, L.N., Jones, M.J., Reed, W.A., Livens, F.R., Charnock, J.M., Mosselmans, J.F.W., Hennig, C., Vaughan, D.J. and Pattrick, R.A.D. (2002) An X-ray absorption spectroscopy study of neptunium(V) reactions with mackinawite (FeS). Environmental Science \& Technology, 36, 179-183.

Nakata, K., Nagasaki, S., Tanaka, S., Sakamoto, Y., Tanaka, T. and Ogawa, H. (2002) Sorption and reduction of neptunium $(\mathrm{V})$ on the surface of iron oxides. Radiochimica Acta, 90, 665-669.

O’Loughlin, E.J., Kelly, S.D., Cook, R.E., Csencsits, R. and Kemner, K.M. (2003) Reduction of uranium(VI) by mixed iron(II)/iron(III) hydroxide (green rust): formation of $\mathrm{UO}_{2}$ nanoparticles. Environmental Science \& Technology, 37, 721-727.

Pecher, K., Haderlein, S.B. and Schwarzenbach, R.P. (2002) Reduction of polyhalogenated methanes by surface-bound $\mathrm{Fe}(\mathrm{II})$ in aqueous suspensions of iron oxides. Environmental Science \& Technology, 36, 1734-1741.

Peretyazhko, T., Zachara, J.M., Heald, S.M., Kukkadapu, R.K., Liu, C., Plymale, A.E. and Resch, C.T. (2008a) Reduction of Tc(VII) by $\mathrm{Fe}(\mathrm{II})$ sorbed on Al (hydr)oxides. Environmental Science \& Technology, 42, 5499-5506.

Peretyazhko, T., Zachara, J.M., Heald, S.M., Jeon, B.H., Kukkadapu, R.K., Liu, C., Moore, D. and Resch, C.T. (2008b) Heterogeneous reduction of Tc(VII) by 
$\mathrm{Fe}(\mathrm{II})$ at the solid-water interface. Geochimica et Cosmochimica Acta, 72, 1521-1539.

Rahnemaie, R., Hiemstra, T. and van Riemsdijk, W.H. (2006a) Inner- and outer-sphere complexation of ions at the goethite-solution interface. Journal of Colloid and Interface Science, 297, 379-388.

Rahnemaie, R., Hiemstra, T. and van Riemsdijk, W.H. (2006b) A new surface structural approach to ion adsorption: tracing the location of electrolyte ions. Journal of Colloid and Interface Science, 293, 312-321.

Rai, D., Felmy, A.R., Sterner, S.M., Moore, D.A., Mason, M.J. and Novak, C.F. (1997) The solubility of Th(IV) and U(IV) hydrous oxides in concentrated $\mathrm{NaCl}$ and $\mathrm{MgCl}_{2}$ solutions. Radiochimica Acta, 79, 239-247.

Regenspurg, S., Schild, D., Schafer, T., Huber, F. and Malmstrom, M.E. (2009) Removal of uranium(VI) from the aqueous phase by iron(II) minerals in presence of bicarbonate. Applied Geochemistry, 24, $1617-1625$.

Ridley, M.K., Hiemstra, T., van Riemsdijk, W.H. and Machesky, M.L. (2009) Inner-sphere complexation of cations at the rutile-water interface: A concise surface structural interpretation with the $\mathrm{CD}$ and MUSIC model. Geochimica et Cosmochimica Acta, 73, $1841-1856$.

Robie, R.A. and Hemingway, B.S. (1995) Thermodynamic properties of minerals and related substances at $298.15 \mathrm{k}$ and 1 bar $\left(10^{5}\right.$ pascals $)$ pressure and at higher temperatures. U.S. Geological Survey Bulletin, 2131, 461pp.

Sani, R.K., Peyton, B.M., Amonette, J.E. and Geesey, G.G. (2004) Reduction of uranium(VI) under sulfatereducing conditions in the presence of $\mathrm{Fe}$ (III)(hydr)oxides. Geochimica et Cosmochimica Acta, 68, 2639-2648.

Scott, T.B., Allen, G.C., Heard, P.J. and Randell, M.G. (2005) Reduction of U(VI) to U(IV) on the surface of magnetite. Geochimica et Cosmochimica Acta, 69, $5639-5646$.

Senko, J.M., Mohamed, Y., Dewers, T.A. and Krumholz, L.R. (2005) Role for Fe(III) minerals in nitrate-dependent microbial U(IV) oxidation.
Environmental Science \& Technology, 39, 2529-2536.

Stefánsson, A. (2007) Iron(III) hydrolysis and solubility at $25^{\circ} \mathrm{C}$. Environmental Science \& Technology, 41, $6117-6123$.

Stefansson, A., Seward, T.M. and Gunnarsson, I. (2007) The hydrolysis and cloro $[\mathrm{sic}]$ complexation of iron(III) in hydrothermal solutions. Geochimica et Cosmochimica Acta, 71, A969.

Stubbs, J.E., Veblen, L.A., Elbert, D.C., Zachara, J.M., Davis, J.A. and Veblen, D.R. (2009) Newly recognized hosts for uranium in the Hanford Site vadose zone. Geochimica et Cosmochimica Acta, 73, $1563-1576$

Wang, Z.M., Zachara, J.M., McKinley, J.P. and Smith, S.C. (2005a) Cryogenic laser induced U(VI) fluorescence studies of a U(VI) substituted natural calcite: Implications to U(VI) speciation in contaminated Hanford sediments. Environmental Science \& Technology, 39, 2651-2659.

Wang, Z.M., Zachara, J.M., Gassman, P.L., Liu, C.X., Qafoku, O., Yantasee, W. and Catalano, J.G. (2005b) Fluorescence spectroscopy of U(VI)-silicates and U(VI)-contaminated Hanford sediment. Geochimica et Cosmochimica Acta, 69, 1391-1403.

Yanina, S.V. and Rosso, K.M. (2008) Linked reactivity at mineral-water interfaces through bulk crystal conduction. Science, 320, 218-222.

Zachara, J.M. (editor) (2005) Uranium geochemistry in vadose zone and aquifer sediments from the 300 area uranium plume. Report PNNL-15121. Pacific Northwest National Laboratory, Richland, WA, USA.

Zachara, J.M., Smith, S.C., Liu, C.X., McKinley, J.P., Serne, R.J. and Gassman, P.L. (2002) Sorption of $\mathrm{Cs}^{+}$to micaceous subsurface sediments from the Hanford Site, USA. Geochimica et Cosmochimica Acta, 66, 193-211.

Zachara, J.M., Heald, S.M., Jeon, B.H., Kukkadapu, R.K., Liu, C.X., McKinley, J.P., Dohnalkova, A.C. and Moore, D.A. (2007) Reduction of pertechnetate $\mathrm{Tc}(\mathrm{VII})$ by aqueous $\mathrm{Fe}(\mathrm{II})$ and the nature of solid phase redox products. Geochimica et Cosmochimica Acta, 71, 2137-2157.

\section{Appendix: thermodynamic modelling}

The standard free energies of formation for $\mathrm{Fe}^{2+}(\mathrm{aq})$ and $\mathrm{Fe}^{3+}(\mathrm{aq})$ were taken from Robie and Hemingway (1995). Thermodynamic data for aqueous $\mathrm{Fe}(\mathrm{II})$ hydrolysis species were then calculated from the hydrolysis constants given by Martell and Smith (2003) and for Fe(III) species using the hydrolysis constants from the recent review by Stefánsson (2007). Thermodynamic data for the iron oxyhydroxide phases was also taken from the review by Stefánsson (2007) except for magnetite which is from Robie and Hemingway (1995). All thermodynamic data for $\mathrm{Np}$ species was taken from the compilation of Lemire et al. (2001). For uranium, thermodynamic data for $\mathrm{UO}_{2}(\mathrm{am})$ is from Rai et al. (1997). All other thermodynamic data for aqueous species of U(IV) 


\section{INTERFACIAL REACTIVITY OF RADIONUCLIDES}

and U(VI) are from the compilation of Guillaumont and Mompean (2003). The calculations were performed using the GMIN computer program (Felmy, 1990) which includes Pitzer ioninteraction parameters from the tabulation of Felmy and Rai (1999). However, since our calculations were for relatively dilute solutions (ionic strength $\sim 0.01$ ) the ion-interaction parameters do not contribute significantly to the final calculated activity coefficients, and the Pitzer formalism reduces to Pitzer's form of the extended Debye-Hückel equation. 
